\title{
THE EFFECT OF SELF ESTEEM TOWARDS CONSUMPTIVE BEHAVIOUR IN X UNIVERSITY STUDENTS
}

\author{
PENGARUH HARGA DIRI TERHADAP PERILAKU KONSUMTIF \\ DI X UNIVERSITAS MAHASISWA
}

\author{
By : \\ Dhea Prastika Setiono ${ }^{1}$ \\ Retno Dwiyanti²
}

\begin{abstract}
Submitted:

26 Februari 2020

Revision:

19 Mei 2020

Accepted:

26 Mei 2020

This study aims to examine the effect of self esteem on consumptive behavior in $\mathrm{X}$ University students. The method in this study uses a quantitative approach. The subjects of this study were 50 University $\mathrm{X}$ students. Data were collected using a self esteem scale instrument and a scale of consumptive behavior with a validity test using the product moment correlation technique, while the reliability test was using an alpha cronbrach technique. The self esteem scale has a reliability score of 0.960 while the consumer behavior scale has a reliability score of 0.891 . Based on the results of data analysis that has been done, the results show that: there is an influence of self esteem with consumptive behavior in University $\mathrm{X}$ students. It is proven that the R. count value is greater than the R. table that is $0.296>0.284$ and the value of $\mathrm{P}=0.000(\mathrm{P}<0.05)$.
\end{abstract}

Keywords: Self Esteem; Consumptive Behaviour; Student.

\begin{abstract}
ABSTRAK
Penelitian ini bertujuan untuk menguji pengaruh harga diri terhadap perilaku konsumtif pada mahasiswa X Universitas. Metode dalam penelitian ini menggunakan pendekatan kuantitatif. Subjek penelitian ini adalah 50 mahasiswa Universitas X. Pengumpulan data menggunakan instrumen skala harga diri dan skala perilaku konsumtif dengan uji validitas menggunakan teknik korelasi product moment, sedangkan uji reliabilitas menggunakan teknik alpha cronbrach. Skala harga diri memiliki skor reliabilitas 0,960 sedangkan skala perilaku konsumen memiliki skor reliabilitas 0,891. Berdasarkan hasil analisis data yang telah dilakukan didapatkan hasil bahwa: terdapat pengaruh harga diri dengan perilaku konsumtif pada mahasiswa Universitas X. Terbukti nilai R. hitung lebih besar dari nilai $R$. tabel yaitu $0,296>0,284$ dan nilai $P=0,000(P<0,05)$.
\end{abstract}

Kata kunci: Harga Diri; Perilaku Konsumtif; Siswa.

\section{INTRODUCTION}

Adolescence is a period of development that is very important for human development. Because in adolescence, we experience a transition between childhood into adulthood. And during the transition period, there are many cognitive, biological, and socio-emotional changes (Santrock, 2005). A person is said to be a teenager when he is 11 to 24 years old,

\footnotetext{
${ }^{1}$ Dhea Prastika Setiono, Universitas Muhammadiyah Purwokerto, dheaprastikasetiono@gmail.com

2 Retno Dwiyanti, Universitas Muhammadiyah Purwokerto, retnodwiyanti@ump.ac.id
} 
while a late teenager is in the age range of 18 to 24 years. In addition, adolescence is a transitional period marked by psychological changes such as, the emergence of various kinds of feelings such as feelings of wanting to be free from power, searching and finding selfidentity, curiosity, the formation of peer groups and so on (Sarwono, 1994).

Teenagers tend to follow the ongoing trend. The problem is, the majority of adolescents who follow this trend sometimes cannot distinguish priorities. The Ministry of National Education said that $50 \%$ of mall or shopping center visitors were teenagers (Kementrian Pendidikan Nasional, 2010). Maybe some teenagers make the mall or shopping center a place to gather with friends, because the mall or shopping center is a crowded place and a place where teenagers easily find something they want. But gradually the mall or shopping center becomes a place for teens to spend money. Buying goods that are not in accordance with the needs cause a person tends to behave consumptively.

The fact is based on the results of an interview on September 21, 2019, conducted by researchers who interviewed one of the students of the University of MuhammadiyahPurwokerto namely the subject of FT. The subject said when the subject bought clothes, sometimes the subject forgot that before the subject had the same color and the same model. The same thing was experienced by subjects with the initials VGC. The subject said that every twice a week the subject stopped by the shopping center to just hang out with friends or play. But the problem that is often faced is when you are in a shopping center and see clothes or good items, sometimes the subject cannot resist not to buy it. Moreover, the subject is very fond of goods in one store called Uniqlo. The subject was very happy to use the services of entrusted goods to buy goods whose store location was outside the city.

Coopersmith, 1967 (Wangge,\& Hartini, 2013)defines self-esteem as an evaluation made by an individual about himself, where the evaluation is the result of interaction between the individual with his environment and the treatment of others against him. Someone who has a high enough self esteem believes if they are a successful person, accepting one's own condition, feeling happy, and able to meet environmental expectations and can accept failure in a natural and realistic manner and more confident. Whereas someone who has a fairly low self esteem tends to not have confidence in themselves (Coopersmith, 1967). Self Esteem is an evaluation carried out by someone both in positive and negative ways towards a particular object, namely oneself (Rosenberg, 1965). In addition, self esteem can also be defined as a self-evaluation made by each individual, the attitude of others towards themselves, ranging from the very negative or very positive (Baron \& Byrne, 2003).

Self Esteem is a dimension of overall evaluation of oneself (Santrock, 2003). Satisfaction of the needs that originate from self esteem gives rise to feelings and attitudes of confidence, worth, ability, and useful and important feelings in the world. Satisfaction of the need for a sense of self-esteem will bring about an attitude of confidence, a sense of worth, a sense of strength, a sense of ability, and a feeling of being useful. Every person has two categories, namely the need for appreciation consists of respecting oneself and obtaining appreciation from others (Alwisol, 2006). Self Esteem can be said as someone towards oneself along the positive - negative dimensions. it can also be seen from self-evaluation; having high self esteem means that someone likes himself. On the other hand, if someone has low self esteem, it indicates that the individual feels uncomfortable about himself (Imhonde, 2013). Low self esteem has to do with anger and hostility. Teenagers who have low self esteem may have mental problems, including anxiety and depression (Lök, Bademli, \& Canbaz, 2017). High self esteem is the result of fulfilling the role needs and in line with one's ideal self (Stuart \& Laraia, 1998). 
Self esteem refers to the overall feeling a person has of values or values. This is considered as a kind of measure of how much someone ‘appreciates, approves, appreciates, appreciates or likes himself (Adler, 2004). Based on the description above it can be analyzed that self esteem is the result of one's assessment of oneself as a valuable person, important, capable and useful that refers to the overall feeling of a person towards himself, ranging from bad to good.Consumptive behavior is an act that is carried out excessively on the use of a product. Someone who behaves consumptively usually buys goods that are not based on certain reasons but only for mere pleasure. For example, buying the same clothes with different brands in order to look attractive in the eyes of the general public (Sumartono, 2002). Furthermore, consumptive behavior is also an act of using goods or products in an incomplete manner. That is, someone buys a product / item not because the product / item used is out of date or outdated, but because of the lure of gifts offered or even the product / item is in trend (Sumartono, 2002).

Consumptive behavior is wasteful and excessive consuming behavior, which prioritizes wants over needs, and there is no priority scale or can also be interpreted as a luxurious lifestyle (Sembiring, 2009). Consumptive behavior generally occurs in adolescents, but in their development they will become adults with a consumptive lifestyle (Tambunan, 2001). Consumptive behavior is an action to buy goods that are not actually taken into account so that they can be said to be excessive (Anggarasari, 1997). In general, female college students tend to be more consumptive than students. Usually, female students have special characteristics in dressing, dressing up, hair style, behavior, fun of music, in meetings and parties. (Monks, 2004).

Consumptive behavior is very dominant in female students' environment (Sumartono, 2002). Someone is said to behave consumptively when it is at the stage of purchasing an item without any rational consideration and not due to needs. And already on the tarap excessive desire.(Lina \& Rosyid, 1997). Consumptive behavior can occur because the community has a materialistic tendency, and a great desire to own an item without considering the needs and most of the purchases made on the basis of encouragement or a great desire to fulfill merely desires (Tambunan, 2001). Consumerism shows a lifestyle of someone with an extraordinary desire to meet their excessive consumption needs. The phenomenon that often arises is the fulfillment of desires without considering the consequences that accompany them, especially the relationship with economic potential.

Consumerism culture is an understanding that is used as a lifestyle that considers luxury goods as a measure of happiness, pleasure, and self-satisfaction. This culture of consumerism can be said as an example of a lifestyle that is not thrifty, if the culture of consumerism becomes a lifestyle that can lead to the emergence of needs that can never be satisfied by what is consumed and makes people continue to consume. Some even all levels of society have not been able to prioritize between goods that must be fulfilled with mere desires (Djuwitaningsih, 2018).

Buying an item is actually not a problem as long as it becomes a necessity. However, if the purchase of goods is not based on needs or the purchase is only based on desire, especially if the purchase is excessive, then it is called consumptive behavior and consumptive behavior including negative actions.Lifestyle is one of the factors that can influence consumer behavior (Susanto, 2013). A person's lifestyle will show their life patterns that are reflected through their activities, interests and opinions in interacting in the surrounding environment. Lifestyle adopted by someone will affect the needs, desires, and behavior including buying behavior (Yuniarti, 2015).

The purpose of this study was to determine whether there is an influence of self-esteem on consumer behavior in university students $\mathrm{x}$. The benefits of this research are expected to 
be input for the development of science and provide scientific insights in the field of industrial \& organizational psychology in aspects of consumer behavior.

\section{METHOD}

The sample in this study amounted to 50 students of University X. Data collection methods in this study used a scale of self esteem and a scale of consumptive behavior. The type of scale used is the Likert scale. Likert scale is used to measure the attitudes, opinions and perceptions of a person or group of people about social phenomena (Sugiyono, 2014). The scale is arranged based on the development of behavioral indicators in accordance with aspects inherent in each variable. According to Coopersmith, 1967 (Irawati, 1997). aspects of self-esteem consist of: self-acceptance, self-confidence, interpersonal relationships, and the ability to deal with the environment. While aspects of consumptive behavior according to (Lina \& Rosyid, 1997) include: Impulsive buying (Wasteful buying), Wasteful buying, Nonrational buying.

Based on the results of the validity test for the tryout scale self-esteem and consumer behavior scale at $n=50$ obtained Rtabel of 0.296 with a significance level of $5 \%$. The results of the validity test of self-esteem scale move from 0.293 to 0.686 . And from 40 items of selfesteem scale available, there are 15 items that fall because the validity value is less than 0.284 . While the results of the validity test of the consumer behavior scale move from 0.288 to 0.531 . And of the 40 items on the scale of consumptive behavior available, there are 19 items that fall because the validity value is less than 0.284 .

Based on the results of the reliability test the self-esteem scale obtained $\alpha$ value of 0.920 . As for the $\alpha$ value on the consumer behavior scale that is 0.891 . Thus both scales have alpha croncbrach reliability coefficient close to 1 which means that there is consistency in the results of the measuring instrument (Azwar, 2010). The reliability range is from 0 to 1.00 (Azwar, 2010)The higher the reliability coefficient near 1.00, the higher the reliability.

\section{RESULT AND DISCUSSION}

The analysis of the data used in this study is simple linear analysis using quantitative data. The statistical test method used is to use the SPSS computer program for Windows version 23.00. The analysis of the data done is as follows: The scholars' hypothesis of the test using $\mathrm{f}$, are derived from significant calculations of self's influence on consumer behavior at $0,000<0.05$, which can therefore conclude that there is a self-reliance influence on consumer behavior in university university university students of x.d.

Table 1.

Hypothetical Test

\begin{tabular}{lllllll}
\hline \multirow{2}{*}{ Model } & Sum & of & \multirow{2}{*}{ df } & Mean Square & F & \multirow{2}{*}{ Sig } \\
\hline & Squares & & & & \\
Regression & 3504.670 & 1 & 3504.670 & 20.188 & $.000^{\mathrm{b}}$ \\
Residual & 8332.710 & 48 & 173.598 & & \\
Total & 11837.380 & 49 & & & \\
\hline
\end{tabular}

a. Dependent Variabel : Consumptive Behaviour

b. Predictors: (constant), Self Esteem

The researchers did a t test that had a value less than the table $t$ value. Recognized the significance of interpersonal communication effects on the irritating smartphone is $0,000<$ 
0.05. It may be concluded, therefore, that to a degree there is a very significant negative influence on self - sustaining variables towards consumptive behavior, so that hypotheses are accepted. The higher self reliance is the lower one's consumptive behavior and the lower one's self-esteem the higher one's consumptive behavior.

Table 2.

Hypothetical Test

\begin{tabular}{llllll}
\hline \multirow{2}{*}{ Model } & \multicolumn{2}{l}{ Unstandardized Coefficients } & $\begin{array}{l}\text { Standardized } \\
\text { Coefficients } \\
\text { Beta }\end{array}$ & $\mathrm{t}$ & Sig \\
& $\mathrm{B}$ & Std.Error & Beta & & \\
\hline (Constant) & 74.132 & 6.358 & & 11.660 & .000 \\
Self Esteem & -.430 & .096 & -.544 & -4.493 & .000 \\
\hline
\end{tabular}

a. Dependent Variable: Consumptive Behaviour

According to the chart above, it is learned that a contant value of 72.132, whereas a self efficiencies (b/coefficient regression) value is. 430 so that the regression equation can be written as follows: $\mathrm{Y}$ equals intuition plus bx, so $\mathrm{Y}=72.132+-0.430 \mathrm{x}$.

The $b$ coefficient is called the direction of regression and states the average change in $y$ for any change in $x$.

Table 3

Hypothetical Test

\begin{tabular}{|c|c|c|c|c|c|c|c|c|c|}
\hline \multirow[b]{2}{*}{ Model } & \multirow[b]{2}{*}{$\mathrm{R}$} & \multirow[b]{2}{*}{$\begin{array}{l}\mathrm{R} \\
\text { Square }\end{array}$} & \multirow[b]{2}{*}{$\begin{array}{l}\text { Adjusted } \\
\mathrm{R} \\
\text { Square }\end{array}$} & \multirow{2}{*}{$\begin{array}{l}\text { Std. } \\
\text { Error of } \\
\text { the } \\
\text { Estimate }\end{array}$} & \multicolumn{2}{|c|}{ Change Statistics } & \multirow[b]{2}{*}{ df1 } & \multirow[b]{2}{*}{ df2 } & \multirow[b]{2}{*}{$\begin{array}{l}\text { Sig. F } \\
\text { Change }\end{array}$} \\
\hline & & & & & $\begin{array}{l}\mathrm{R} \\
\text { Square } \\
\text { Change }\end{array}$ & $\begin{array}{l}\text { F } \\
\text { Change }\end{array}$ & & & \\
\hline 1 & $.544^{a}$ & .296 & 281 & 13.176 & .296 & 20.188 & 1 & 48 & .000 \\
\hline
\end{tabular}

a. Predictors: (Constant), Self Esteem

Based on the results of the rsquare determinative coefficient of 0.296 , the ratings reflect that in the study self-absorption contributed $29.6 \%$ to consumer behavior. While $704 \%$ is a donation from other factors (unstudied factor). The study reveals the influence of selfreliance on consumer behavior on university of $\mathrm{x}$. based on regression tests, self-reliance on consumer behavior on university of $\mathrm{x}$, with a degree of $5 \%$ significance gaining fcalculate $=$ 20.188 and ftabel $=4.04$. So fatuity $>$ chart. Then it got sig $(\mathrm{p})=0,000(\mathrm{p}<0.05)$ and thitung $<$ ttabel $(-4.493<1,677)$. This suggests that the hypothesis is adduced that there is a significant influence in self-destruct with consumer behavior. Meaning the lower self selfesteem the person the higher his consumptive behavior.

The $b$ coefficient is called the direction of regression and states the average change in $y$ for any change in $x$. Thus can be concluded that self-reliance will transform by $-0,430$ for any change that occurs in consumptive behavior. The influence between the two variables above conforms to the research conducted by (Gunawan, 2003) stating that self requires to create a positive attitude that will affect individual behavior. The lack of self-restraint that a youth has will make the teen lose his confidence so that in acceptance of his or her social environment, which results in his behavior (Sari, 2004) Low self-esteem would cause problems for an adolescent. The youth who give meaning to self - acceptance and low self-esteem, will appeal to their behavior to defend themselves. Low self-worth and self-worth result in youth having a low regard for doing their own interests and activities, so there is an imbalance between the needs and wants that engender consumer behaviors to defend themselves and become equal to others. The imbalance experienced by the youth results in strong behavior as a result of the direction the youth needs focus on a specific object. 
People who have higher self-esteem usually would not engage in buying behavior to boost their already high self-esteem, which is consistent with previous research (Chang \& Arkin, 2002). Teenagers are usually easily seduced by advertising enticements and tend to be drawn into the company of unrealistic and wasteful friends, so the traits of the youth the producer exploited into the world of youth. The results of this study differ from the results of Opiri and Lang's (2016) research which states that social values significantly influence both attitudes towards luxury fashion and purchase intentions, but are not influenced by selfesteem.

\section{CONCLUSION}

The results of the study showed that self reliance on consumer behavior in university university student $\mathrm{x}$. also, based on analysis results that lead to rsquare determinative coefficient 0.296 , the rating reflected that self expanded to give a contribution of $29.6 \%$ to consumer behavior. While $704 \%$ is a donation from other factors (unstudied factor). Also noteworthy is the significance of interpersonal communication effects on the irritating smartphone $0,000<0.05$ and the thitung value of $-4.493<$ ttabel 1,677. It may be concluded, therefore, that to a degree there is a very significant negative influence on self - sustaining variables towards consumptive behavior, so that hypotheses are accepted. The higher self reliance is the lower one's consumptive behavior and the lower one's self-esteem the higher one's consumptive behavior. And that is based on significant calculations of self - awareness impact on consumer behavior at 10,000 to 0.05 and an $\mathrm{f}$ value. Add $20.188>\mathrm{f}$. table 4.04, thus concluding that there is a self sustaining influence on consumer behavior in university university students of $\mathrm{x}$.

\section{REFERENCES}

Adler, N. \& S. J. (2004). Self-Esteem. Research Network on Socioeconomic Status and Health. Retrieved November 24, 2019, from http://www.macses.ucsf.edu/Research/Psychosocial

Alwisol. (2006). Psikologi Kepribadian. Malang: UMM Press.

Anggarasari. (1997). Hubungan Tingkat Religiusitas Dengan Sikap Konsumtif Pada Ibu Rumah Tangga. Psikologika: Jurnal Pemikiran Dan Penelitian Psikologi, 2(4), 15-20. https://doi.org/10.20885/psikologika.vol2.iss4.art2

Azwar, S. (2010). Reliabilitas dan Validitas. Yogyakarta: Pustaka Belajar.

Baron, R. A., \& Byrne, D. (2003). Psikologi Sosial. Jakarta: Erlangga.

Chang, L.C., Arkin, R. (2002). Materialism as an attempt to cope with uncertainty. Psychology and Marketing, 19(5), 389-406.

Coopersmith. (1967). The Antecedents of Self-Esteem. San Fransisco: W.H Freeman Company.

Djuwitaningsih, E. W. (2018). Perubahan Perilaku Konsumtif dan Gaya Hidup Tenaga Kerja Wanita (TKW) Purna. Aristo, 7(1), 01. https://doi.org/10.24269/ars.v7i1.1284

Gunawan, A.W. (2003). Genius Learning Strategy, Petunjuk Praktis Untik Menerapkan Accelerated Learning. Cetakan Pertama Oktober. Jakarta: Gramedia Pustaka.

Imhonde, H. O. (2013). Self-esteem, Gender, Family-communication-style and Parental Neglect as Predictors of Aggresive Tendencies among Secondary School Adolescents. International Journal of Public Health Science (IJPHS), 2(3), 93-100. https://doi.org/10.11591/ijphs.v2i3.2873 
Irawati, N.G. (1997). Hubungan antara Harga Diri Remaja Putri dengan Minat Membeli Kosmetika Bermerk. Universitas Gajah Mada.

Kementrian Pendidikan Nasional. (2010). Mengejar Remaja Sampai ke Mall. Retrieved from http://www.suaramerdeka.com/harian/0602/18/slo10.htm.

Lina, \& Rosyid, H. F. (1997). Perilaku Konsumtif Berdasarkan Locus of Control pada Remaja Putri. Psikologika, 2(4), 5-13.

Lök, N., Bademli, K., \& Canbaz, M. (2017). The Effects of Anger Management Education on Adolescents' Manner of Displaying Anger and Self-Esteem: A Randomized Controlled Trial. Archives of Psychiatric Nursing, 32(1), 75-81. https://doi.org/10.1016/j.apnu.2017.10.010

Monks, F.J., Knoers, A.M., dan Haditono, S. R. (2004). Psikologi Perkembangan: Pengantar dalam Berbagai Bagiannya. Jogjakarta: Gadjah Mada University Press.

Opiri, Jane and Lang, Chunmin. (2016) "The Impact of the Self-esteem and Consumption Values on Consumers Attitude and Intention to Purchase Luxury Fashion Products". International Textile and Apparel Association (ITAA) Annual Conference Proceedings. 121. https://lib.dr.iastate.edu/itaa_proceedings/2016/presentations/121

Rosenberg, M. (1965). Society and The Adolescent Self-Image. Princeton: Princeton University Press.

Santrock, J. (2003). Adolescence, Perkembangan Remaja (Edisi ke e). Jakarta: Erlangga.

Santrock, J. (2005). Adolescence, Perkembangan Remaja. Jakarta: Erlangga.

Sari, K.L. (2004). Hubungan antara Dukungan Sosian dengan Harga Diri pada Remaja. Universitas Ahmad Dahlan Yogyakarta.

Sarwono. (1994). Psikologi Remaja. Jakarta: PT Raja Grafindo Persada.

Sembiring, A. (2009). Budaya Konsumerisme. Internet, (Di akses 24 November 2019). Retrieved

from http://indowarta.com/index.php?option=com_content\&view=article\&id=310:budayakon sumerisme \&catid=102: opini\&Itemid $=374$

Stuart, G. w, \& Laraia, M. T. (1998). Principle and practise of psychiatric nursing. (Elsevier Mosby, Ed.). St Louis Missouri.

Sugiyono. (2014). Metode Penelitian: Kuantitatif, Kualitatif dan R\&D. Metode Penelitian Manajemen. PT Alfabeta.

Sumartono. (2002). Terperangkap Dalam Iklan: Meneropong Imbas Pesan Iklan Televisi. Bandung: PT Alfabeta.

Susanto, A. S. (2013). Membuat Segmentasi Berdasarkan Life Style (Gaya Hidup). Jurnal Jibeka, 7(2), 1-6.

Tambunan, R. (2001). Remaja dan Perilaku Konsumtif. Internet, (Di akses 24 November 2019). Retrieved from http://e-psikologi.com.

Wangge, B.D., \& Hartini, N. (2013). Hubungan Penerimaan Diri dengan Self Identity pada Remaja Pasca Perceraian Orangtua. Jurnal Psikologi Dan Kepribadian, 2(1), 1-6.

Yuniarti, S. (2015). Asuhan Tumbuh Kembang Neonatus Bayi: Balita dan Anak Prasekolah. Bandung: PT Refika Aditama. 